\title{
Analysis of Factors Risk of Falling in The Elderly at The Environment Social Tresna Werdha Minaula Kendari in 2018
}

\author{
Rahmawati Rahmawati', Fitriani Fitriani' ${ }^{2}$, Nurul Fitrah Sulthan ${ }^{3}$, I Putu Sudayasa ${ }^{4}$, \\ La Ode Alifariki ${ }^{5}$ \\ \{my183473@gmail.com ${ }^{1}$, fitriani.dhala@gmail.com ${ }^{2}$, fitrahsulthan20@yahoo.com ${ }^{3}$ \\ dr.putusudayasa@uho.ac.id ${ }^{4}$,ners_riki@yahoo.co.id $\left.{ }^{5}\right\}$ \\ 1,2,3,4,5 Halu Oleo University, Kendari, South East of Sulawesi, Indonesia
}

\begin{abstract}
This research aims to determine the factors associated with the risk of falls in the elderly in Tresna Elderly Social Institution Kendari. This research uses design of Analytical observational with cross sectional. The sample of this study used a proportional random sampling technique of 66 people who were taken based on inclusion and exclusion criteria. Data analysis used chi-square test to see the relationship between independent and dependent variables with a significance level of $p<0.05$. The results showed that intrinsically the elderly with reduced risk of musculoskeletal system function $(86.37 \%)$ and extrinsic factors showed that the environment was at risk $(13.63 \%)$ and the elderly with at risk devices $(19.70 \%)$ of the elderly. The results of the test chi-square showed that the decrease in the musculoskeletal system $p=0.004$, the environment $p=0.419$ and the tool $p=0,000$. The conclusion of this study is that there is a relationship between a decrease in the function of the musculoskeletal system and a tool with the risk of falling in the elderly and no environmental relationship with the risk of falling in the elderly.
\end{abstract}

Keywords: Falling Risk Factors, Elderly

\section{Introduction}

Elderly is part of the process of growth and development. Humans do not suddenly grow old, but develop from babies, children, adults and eventually grow old. This is normal with physical changes and predictable behavior that happens to everyone when they reach the age of a certain stage of development [1]. Therisk of falling is an increase in susceptibility to falls which can cause physical hazards that often occur in the elderly, with increasing age, physical, mental and bodily functions decreasing [2].

Every year an estimated 646,000 people die due to falls and elderly people over 65 years of age who fall 37.3 million experience a fall and need medical help. One of the causes of falls is age factors such as the elderly or the elderly who have the highest risk of death or serious injury caused by falls [3].

The country of Indonesia itself is noted that the elderly with 65 years of age experience annual falls of around $28-35 \%$ and increase at the age of 70 years with a prevalence of $32-42 \%$ [4]. Falling incidents in Indonesia were recorded from 115 orphanage residents as many as 30 elderly or around $43.47 \%$ experienced a fall [4].

Based on the results ofthe research conductedentitled analysis of factors related to the risk of falls in the elderly living at home shows that factors associated with the risk of falls in the 
elderly who live at home are heart problems (58.3\%), limb disorders $(69.8 \%)$, nervous disorders $(56.3 \%)$, impaired vision $(67.7 \%)$, hearing loss $(69.6 \%)$, assistive devices $(33 \%)$, environment $(45 \%)$ [5].

Data from the Southeast Sulawesi Provincial Health Office found 24,290 people with heart disease, 29,583 hypertension and 3,231 people with stroke. The total number of cases is 57,104 . Based on the case data there are some people who have fallen due to the disease [6] Based on preliminary studies conducted by researchers at the Tresna Werdha Minaula Social Home Kendari on 27 September 2018. The total number of elderly people at the Tresna Werdha Minaula Kendari Social Home was 95 people, the average age of the elderly is 60-74 years as many as 47 elderly, 75-90 years as many as 32 elderly, 90 and over as many as 3 elderly. 50 male and female male 45 people. Based on data obtained at the poly clinic at the Kendari Nursing Home in Tresna Werdha Minaula, elderly people who have experienced falls in the past 6 months have 12 elderly.

Based on this phenomenon, the authors are interested in conducting research with the title of analysis of factors related to the incidence of falls in the elderly at the Tresna Werdha Minaula Social Home Kendari.

\section{Research Methods}

The method or design of this research used an observational analytic method with a approach cross sectional, this study tried to gather information about the factors associated with the risk of falling in the elderly at the Tresna Werdha Minaula Social Home Kendari.

This research was conducted in December 2018 at the Tresna Werdha Minaula Social Institution in Kendari.

The population of this study were all the elderly who were on the Tresna Werdha Minaula Social Institution in Kendari, namely 95 people. The sample in this study were some of the elderly who were on the Tresna Werdha Minaula Social Home Kendari. The sampling technique used was proportional random sampling. The technique of collecting data using questionnaires and collecting with chi square (X2) statistics [7].

\section{Results and Discussion}

Characteristics of Research Respondents

Table 1. Characteristics of Respondents by Age, Sex and Pensions.

\begin{tabular}{lcc}
\hline \multicolumn{1}{c}{ Variable } & $\begin{array}{c}\text { Number } \\
(\mathrm{n})\end{array}$ & $\begin{array}{c}\text { Percent } \\
(\%)\end{array}$ \\
\hline Age & & \\
& & $\begin{array}{c}\text { (years) } \\
75-95-5960-74 \\
\end{array}$ \\
$>90$ & 2 & 38234.55 \\
Amount & 66 & 3.03 \\
Gender & & 100 \\
Male & 34 & 52 \\
Female & 32 & 48 \\
Amount & 66 & 100 \\
Guesthouse & & \\
Safe & 6 & 9.09 \\
Sumatra & 6 & 9.09
\end{tabular}




\begin{tabular}{lcc} 
Peaceful & 6 & 9.09 \\
Adil & 6 & 9.09 \\
Makmur & 6 & 9.09 \\
Segar & 4 & 6.06 \\
Bahagia & 7 & 10.60 \\
Sentosa & 7 & 10.60 \\
Flamboyan & 6 & 9.09 \\
Abadi & 4 & 6.06 \\
Bougenvil & 3 & 4.54 \\
Crowded & 5 & 7.6 \\
\hline Total & 66 & 100 \\
\hline
\end{tabular}

Source: Primary data processed in 2018

Table 1 shows that out of 66 respondents there are 38 people $(57.58 \%)$ in the age category of $60-74$ years and the least is 2 people $(3.03 \%)$ in the age category $>90$ years. It can be concluded that the respondents in this study were mostly those aged 60-74 years. Based on sex characteristics, male respondents were 34 people (52\%) and female sex were 32 people (48\%). It can be concluded that there are more male respondents than female respondents. Of the 66 most respondents, Wisma Bahagia 7 people $(10.60 \%)$ and Wisma Sentosa 7 people $(10.60 \%)$ and the least was Wisma Bougenvil 3 people $(4.54 \%)$. It can be concluded that the respondents in this study were mostly at Wisma Bahagia and Wisma Sentosa.

\subsection{Univariate analysis}

Table 2. Distribution of Respondents with a decline in Musculoskeletal System, Environment, Aid, Fall Risk in Elderly Social Institution Tresna Kendari Minaula 2018.

\begin{tabular}{lcc}
\hline \multicolumn{1}{c}{ Variables } & $\begin{array}{c}\text { Total } \\
(\mathrm{n})\end{array}$ & $\begin{array}{c}\text { Percent } \\
(\%) \text { of }\end{array}$ \\
\hline Reduction Musculoskeletal System & & \\
\hline Risk & 57 & 86.37 \\
No Risk & 9 & 1363 \\
\hline Total & 66 & 100 \\
\hline Environmental & & \\
\hline Risk & 9 & 13.63 \\
No Risk & 57 & 86.37 \\
\hline Total & 66 & 100 \\
\hline Aids & & \\
\hline Risk & 13 & 19.70 \\
\hline No Risk & 53 & 80.30 \\
\hline Total & 66 & 100 \\
\hline Risk of Falling & & \\
\hline Risk & 57 & 86.37 \\
No risk & 9 & 13.63 \\
\hline Total & 66 & 100 \\
\hline Source $:$ Primary data in 2018 & &
\end{tabular}

Table 2 shows that of the 66 respondents, the elderly at risk of falling were 57 elderly $(86.37 \%)$ and the elderly who did not risk falling as many as 9 elderly (13.63\%). Judging from 
environmental variables, 9 elderly at risk fell as many as 9 elderly (13.63\%) and elderly who did not risk falling 57 elderly $(86.37 \%)$. Judging from the variable tools, it shows that the elderly at risk of falling as many as 13 elderly (19.70\%) and the elderly who have no risk of falling as many as 53 elderly (80.30\%). Judging from the risk variables falling, it shows that, elderly at risk of falling as many as 57 elderly $(86.37 \%)$ and elderly who have no risk of falling as many as 9 elderly (13.63).

\subsection{Bivariate analysis}

Musculoskeletal System Function Decline Relations with Fall Risk In Elderlyanalysis of factors associated with the risk of falls in the elderly, can be seen in Table 3 .

Table 3. Relationship between Decreasing Musculoskeletal System Function and Risk of Falling in the Elderly at Tresna Werdha Minaula Social Institution Kendari Year 2018.

\begin{tabular}{|c|c|c|c|c|c|c|c|}
\hline \multirow{3}{*}{$\begin{array}{l}\text { Decreased } \\
\text { System } \\
\text { Function } \\
\text { Musculoskel } \\
\text { etal }\end{array}$} & \multicolumn{7}{|c|}{ Risk of Falling in the Elderly } \\
\hline & \multicolumn{2}{|c|}{$\begin{array}{l}\text { Not at } \\
\text { IsRisk }\end{array}$} & \multicolumn{2}{|c|}{ Risk of } & \multicolumn{2}{|c|}{ Number of } & \multirow{2}{*}{$\begin{array}{c}P \\
\text { Value }\end{array}$} \\
\hline & $\mathrm{n}$ & $\%$ & $\mathrm{n}$ & $\%$ & $\mathrm{n}$ & $\%$ & \\
\hline Risk & 5 & 7.57 & 52 & 78.80 & 57 & 100 & \\
\hline No-Risk & 4 & 6.06 & 5 & 7.57 & 9 & 100 & 0,004 \\
\hline Total & 9 & 13.63 & 57 & 86.37 & 66 & 100 & \\
\hline
\end{tabular}

Source : primary data in 2018.

Table 3 shows that of the 66 respondents 57 elderly $(86.37 \%)$ risk of decreased function of the musculoskeletal system and those who did not risk falling as many as 5 elderly $(7.57 \%)$ and the elderly at risk of falling as many as 52 elderly (78.80\%). Elderly who did not risk a decrease in musculoskeletal system function as many as 9 elderly (13.63\%), who did not risk falling there were 4 elderly $(6.06 \%)$ and elderly who risked falling as many as 5 elderly $(7.57 \%)$.

The results oftest, chi-square obtained value $\mathrm{p}(0.004)<\alpha(0.05)$, which means that the alternative hypothesis is accepted and the null hypothesis is rejected, so there is the association of the musculoskeletal system with the risk of falls in the elderly in Tresna Elderly Social Institution Minaula Kendari Year 2018.

Environmental Relationships with Risk of Falling on the Elderly at the Tresna Werdha Minaula Social Institution in Kendari in 2018

Relations with the risk of falling in the elderly can be seen in table 4 .

Table 4. Environmental Relationships with the Risk of Falling in the Elderly at the Tresna Werdha Minaula Kendari Home 2018.

\begin{tabular}{lccccccc}
\hline & \multicolumn{6}{c}{ Risk of Falling in the Elderly } \\
\cline { 2 - 7 } Environment & $\begin{array}{c}\text { Not at } \\
\text { Is Risk }\end{array}$ & Risk of the & $\begin{array}{c}\text { Number } \\
\text { of }\end{array}$ & \multirow{2}{*}{$\begin{array}{c}\boldsymbol{P} \\
\text { Value }\end{array}$} \\
\cline { 2 - 7 } & $\mathrm{n}$ & $\%$ & $\mathrm{n}$ & $\%$ & $\mathrm{n}$ & $\begin{array}{c}\% \\
\text { At }\end{array}$ & \\
\hline Risk & 2 & 3.03 & 7 & 10.60 & 9 & 100 & 0.419 \\
\hline No risk & 7 & 10.60 & 50 & 75.77 & 57 & 100 & \\
\hline
\end{tabular}




\begin{tabular}{ccccccc}
\hline Total & 9 & 13.63 & 57 & 86,37 & 66 & 100 \\
\hline Source : Primary data in 2018 & & & &
\end{tabular}

Table 4 shows that of 66 respondents, 9 elderly with a risky environment (13.63\%), those who did not risk falling were 2 elderly $(3.03 \%)$ and those who were at risk of falling 7 elderly $(10.60 \%)$. Elderly who are not at risk with the environment as many as 57 elderly $(86.37 \%)$, who do not risk falling as many as 7 elderly $(10.60 \%)$ and those at risk of falling as many as 50 elderly $(75.77 \%)$.

Thetest results chi square obtained $p$ value $(0.419)>\alpha(0.05)$, which means that the alternative hypothesis is rejected and the null hypothesis is accepted, so that there is no environmental relationship with the risk of falling on the elderly in Tresna Werdha Minaula Kendari Social Institution in 2018. Aids with the Risk of Falling on the Elderly at the Tresna Werdha Minaula Social Institution Kendari in 2018 The relationship of assistive devices with the risk of falling in the elderly can be seen in table 5 .

Table 5. Relationship between Aid Tools and Risk of Falling in the Elderly in the Social Institution of Tresna Werdha Minaula Kendari in 2018.

\begin{tabular}{cccccccc}
\hline & \multicolumn{6}{c}{ Risk of Falling in the Elderly } \\
\cline { 2 - 7 } Aid for & $\begin{array}{c}\text { Not at } \\
\text { Is Risk }\end{array}$ & $\begin{array}{c}\text { Risk of } \\
\text { the }\end{array}$ & $\begin{array}{c}\text { Amount } \\
\text { of }\end{array}$ & $\begin{array}{c}\boldsymbol{P} \\
\text { Value }\end{array}$ \\
\cline { 2 - 7 } & $\mathrm{n}$ & $\%$ & $\mathrm{n}$ & $\%$ & $\mathrm{n}$ & $\begin{array}{c}\% \\
\text { at }\end{array}$ & \\
\hline Risk & 6 & 9.09 & 7 & 10.60 & 13 & 100 & \\
\cline { 1 - 6 } No Risk & 3 & 4.54 & 50 & 75.77 & 53 & 100 & 0.802 \\
\hline Total & 9 & 13.63 & 57 & 86.37 & 66 & 100 & \\
\hline
\end{tabular}

Source : primary data in 2018.

Table 5 shows that of the 66 respondents, the risk on tools as much as 13 elderly $(19.70 \%)$, risk fell as many as 6 elderly $(19.09 \%)$ and the elderly who did not risk falling as many as 7 elderly $(10.60 \%)$. Elderly people who are not at risk in the tool are 53 elderly $(80.30 \%)$, who do not risk falling as many as 3 elderly $(4.54 \%)$ and those at risk of falling as many as 50 elderly $(75.77 \%)$.

The test results chi square obtained the value of $p$ value $(0,0802)>\alpha(0,05)$, which means that the alternative hypothesis is rejected and the null hypothesis is accepted, so there is no relationship with the risk of falling to the elderly on the Tresna Werdha Minaula Kendari Social Home 2018.

\section{Discussion}

Relations with the musculoskeletal System Function decline Fall Risk in Elderly.

Musculoskeletal disorders cause gait (gait) and is associated with the physiological aging process. All of these changes result in motion weakness, short steps, decreased rhythm, and dilation of basal relief. The feet do not appear strong and are more likely to falter easily. Decrease in reaction results in someone difficult / late anticipating if there is a disturbance such as slipping, tripping, sudden events, making it easier to fall [8].

Based on the results of the test chi-squarethe value of $\rho$ value $>\alpha$ or $0.802>0.05$, which means there is a relationship a decrease in the function of the musculoskeletal system with the risk of falling in the elderly at the Tresna Werdha Minaula Social Home Kendari. 
There is no a relationship because a decrease in the functioning of the musculoskeletal system can cause harm to the elderly and can increase the risk of falls. This is because the elderly who are in the Tresna Werdha Minaula Social Institution in Kendari experience shaking while walking, the knee joints and joints of the ankles are stiff in the morning, the knee and ankle joints hurt during rest, and the elderly experience joint disease (rheumatism arthritis and osteoporosis).

In the elderly who are not at risk of a decrease in the musculoskeletal system but have a risk of falling as many as 5 elderly (7.57\%). This is because the environment of the elderly such as the elderly yard is uneven, items on the yard are not placed in place. The guesthouse terrace has a cracked floor, there are steps (stairs), items are not placed in place. The elderly living room has a folded carpet tip, the furniture in the living room disturbs the road. The elderly bedroom has an uneven floor, there are folded ends of the carpet, items are difficult to reach, there is no storage of items that are easily accessible. The elderly bathroom has no handle on the door, there is a slippery floor. In addition there are elderly people who use the three tools including sticks, wheelchairs and footwear such as sandals so that the elderly risk falling.

This study is also similar to researchthat there is a relationship between disorders of the musculoskeltal system and the risk of falls in the elderly. Where there were 25 respondents $(56.8 \%)$ who had a musculoskeletal system disorder and were at risk of falling 44 respondents.

This study is similar to study that the results of the study show that there is a relationship between limb disorders and the risk of falls in the elderly. Where the results of his research show that as many as 67 respondents experienced impaired limbs [5].

The Relationship of the Environment with the Risk of Falling in the Elderly The environment often associated with falls in the elderly includes old household/home appliances or lying on the floor, places that are not strong hold, low or slippery beds/bathrooms, difficult items reached, the floor is not flat, slippery, or declining, carpets that are not held properly, lighting that is not good (less bright or dazzling) [9].

The results of the test chi-square get the value $\rho$ value $>\alpha$ or $0.419>0.05$, which means the null hypothesis is accepted and the alternative hypothesis is rejected. So that there is no environmental relationship with the risk of falling on the elderly at the TresnaWerdha Minaula Social Home Kendari.

There is no environmental relationship with the risk of falling due to several factors, namely, the neighborhood of the orphanage has been renovated so that the neighborhood of the institution is neatly arranged, the plant in the courtyard does not disturb the road, the old parlors are replaced with new ones, the items are put in place, the beds / the bathroom is not down and not slippery, the items are easily accessible, there are no items that can trip over, the floor is flat and not slippery, and the lighting outside and inside the guesthouse is good and not dazzling.

In an environment that is not risky but has the risk of falling as many as 50 elderly $(75.77 \%)$. This is because the elderly experience a decrease in the function of the musculoskeletal system such as experiencing limb disorders, difficult ankles to move, feeling trembling when walking far away, having a joint disease, painful knee joints at rest, feeling stiff at the knee joint, stiff ankles when rest, knees stiff in the morning, swelling in the joints and some elderly use walking aids such as sticks, crutches and wheelchairs.

In a risky environment but not at risk of falling as many as 2 elderly (3.03\%). This is because the elderly do not experience a decrease in the musculoskeletal system and do not use assistive devices. 
This research is similar to a study conducted by [9] that the results of the study showed no environmental relationship with the risk of falls in the elderly. Where a good environment with low risk falls with the number of respondents as many as 18 respondents and respondents who have a bad environment low risk falls with the number of respondents 10 .

This research is not in accordance with the research conducted by [10] which explains that the environment is not good. is one of the causes of falls in the elderly where $72.3 \%$ of the elderly were at risk of falling high in Tehran Hospital from 125 respondents.

Equipment Relationships with the Risk of Falling Elderly Theuse of walking aids does help improve balance, but on the other hand causes discontinuous steps and the tendency of the body to bend, especially if the device does not use wheels, therefore the use of walking aids should be recommended individually. If the case goes to the elderly can not be handled with medication or surgery, then one treatment is with a walking aid such as a cane (cane), crutch (crutches), and walker.When choosing a walking aid, the anatomy of the body and the angle of the elbow must be considered because many of them cannot get professional help resulting in gait worsening which can trigger the risk of falling.

The results of thetest chi-square get the value $\rho$ value $<\alpha$ or $0.802>0.05$, which means there is no correlation between the tool and the risk of falling in the elderly at the Tresna Werdha Minaula Social Home Kendari.

There is no relationship between the tool and the risk of falling due to several elderly people who have consulted their assisted equipment to the Tresna Werdha Minaula Social Institution in Kendari to avoid injury, so that the tools used by the elderly are according to their needs or according to the standard, the stick used by the elderly elderly body height, not broken/cracked, elderly wheelchair locks function properly and wheelchair tires are not smooth /slippery, the type of assistive equipment provided is in accordance with the needs of the elderly.

The elderly with assistive devices are not at risk but have a risk of falling as many as 56 elderly $(84.85 \%)$. This is because the elderly have decreased musculoskeletal system function such as having limb disorders, difficult ankles to move, having joint disease, painful knee joint at rest, feeling stiff at the knee joint, feeling trembling when walking away, stiff ankles when rest and knee stiffness in the morning, there is swelling in the supply. In the elderly environment such as the uneven elderly yard, items in the yard are not placed in place. The guesthouse terrace has a cracked floor, there are steps (stairs), items are not placed in place. The elderly living room has a folded carpet tip, the furniture in the living room disturbs the road. The elderly bedroom has an uneven floor, there are folded ends of the carpet, items are difficult to reach, there is no storage of items that are easily accessible. The elderly bathroom has no handle on the door, there is a slippery floor.

This study is not in accordance with research conducted by where there were 12 respondents $(25.0 \%)$ who used walking aids at risk of falling from 48 respondents [11].

\section{Conclusion}

1. There is a decrease in the function of the musculoskeletal system with the risk of falling in the elderly at the Tresna Werdha Minaula Social Home Kendari.

2. There is no environmental relationship with the risk of falling on the elderly at the Tresna Werdha Minaula Social Home Kendari. 
3. There is a relationship between assistive devices and the risk of falling in the elderly at the Tresna Werdha Minaula Social Home Kendari.

\section{Suggestions For}

1. Institutions and Professionals.

The results of this study can be used as a reference for management in the field of nursing especially regarding the risk of falls that occur in the elderly and can be a useful source of information.

2. For Tresna Werdha Minaula Social Institution Kendari.

a. Seeing the high risk of falling in the decline in the function of the musculoskeletal system above, it is expected that the institution focuses on the health level of the elderly itself.

b. For the environment, it is expected that it is necessary to create a safe and comfortable environment to minimize the fall in the elderly.

c. In aids, it is hoped that the orphanage will pay more attention to the tools used by the elderly.

3. For the Elderly

The results of this study can be used as a source of information so that the elderly can prevent risk factors from falling.

\section{References}

[1] Azizah L. Elderly Nursing. Yogyakarta, Graha Ilmu, 2011.

[2] D M. Hubungan Penerapan Tindakan keselamatan Pasien oleh Perawat Pelaksana dengan Kepuasan pasien di RSU Soetomo Surabaya. 2008; Available from: http://lib.ui.ac.id/file?file=digital/2016-10/124691-Dewi Maryam.pdf, 2016.

[3] WHOs (Would Health Organization). Target 6: Reduce prevalence of raised blood pressure. In Jenewa; Available from: https://www.who.int/nmh/ncd-tools/target6/en/, 2017.

[4] Kementrian Kesehatan Republik Indonesia. Pusat Data dan Informasi Kementrian Kesehatan RI. In Jakarta: Kemkes RI;, 2013.

[5] Fristantia Dwi Agnes, Zulfitri, Reni, N YH. Analisis Faktor- Faktor yang Berhubungan dengan Risiko Jatuh Pada Lansia yang Tinggal di Rumah. J Online Mhs Bid Ilmu Keperawatan [Internet]. Available from: http://onesearch.id/Record/IOS1766.article18805\#details, 2018.

[6] Dinkes Propinsi Sultra. Profil Kesehatan Sulawesi Tenggara Tahun 2016. In Propinsi Sulawesi Tenggara, 2017.

[7] Arikunto. Prosedur Penelitian Suatu Pendekatan Praktik. Jakarta: Rineka Cipta, 2010.

[8] Darmojo, B,. Dan Martono H. Buku Ajar Geriatri (Ilmu Kesehatan Usia Lanjut). Jakarta: Balai Penerbit Fakultas Kedokteran Universitas Indonesia, 2004.

[9] APS Healthcare. Fall Prevention Resource Guide [Internet]. North Huntingdon: Southwestern; Available from: http://www.astho.org/Prevention/Healthy-Aging/VDMFalls-Prevention-Resource-Guide/, 2010.

[10] Cahayaningtyas R. Analisis Faktor-Faktor yang Mempengaruhi Risiko Jatuh pada Lansia di Posyandu Ngudi Rahayu Gedongkiwo Antrijeron Yogyakarta. Available from: http://repository.umy.ac.id/handle/123456789/22948, 2018.

[11] Jamebozorgi AA, Kavoosi A, Shafiee Z, Kahlaee AH, Raei M. Investigation of the prevalent fall-related risk factors of fractures in elderly referred to Tehran hospitals. Med J Islam Repub Iran. Feb; 27(1):23-30, 2013. 
